\title{
Colonic lithobezoar, a rare cause of ileus
}

\author{
Kolonik litobezoar, nadir rastlanan bir ileus nedeni \\ Hakan Özdemir, Zehra Ünal Özdemir, Metin Şenol*, İbrahim Tayfun Şahiner \\ General Surgery Clinic (H. Özdemir, MD, Z. Ü. Özdemir, MD, M. Şenol, MD, İ. T. Şahiner, MD), \\ Nevsehir State Hospital, TR-50300 Nevşehir
}

\begin{abstract}
The accumulation of undigested foreign bodies or nutrients in gastrointestinal tract is named as bezoar. These foreign bodies can be hair (trichobezoar), fibers or seeds of vegetables and fruits (pythobezoar), remnants of milk (lactobezoar) and stones (lithobezoar). Lithobezoar is mostly seen in the stomach and rarely in the colon. Colonic lithobezoar is usually seen in iron deficiency anaemia, pica or psychologically ill patients. It can be the reason for mechanical intestinal obstruction and ileus at these patients. In this case, we present a 35-year-old schizophrene patient with colonic lithobezoar who presented by ileus.
\end{abstract}

Keywords: Bezoar, lithobezoar, ileus

\section{Özet}

Sindirilemeyen besin ya da yabancı cisimlerin gastrointestinal sistemde birikmesi bezoar olarak adlandırılır. Bu yabancı cisimler saç (trikobezoar), sebze ve meyvelerin lif ya da çekirdekleri (fitobezoar), süt kalıntıları (laktobezoar) ve taşlar (litobezoar) olabilir. Litobezoar çoğunlukla midede ve nadiren de kolonda görülür. Kolonik litobezoar genellikle demir eksikliği anemisi, pica ya da psikiyatrik hastalarda görülür. Bu hastalarda mekanik barsak tıkanıklığı ve ileusa neden olabilir. Bu olguda, iluesla başvuran ve kolonik litobezoarı olan 35 yaşında bir şizofreni hastası sunulmaktadir.

Anahtar sözcükler: Bezoar, litobezoar, ileus

Geliş tarihi/Received: March 06, 2013; Kabul tarihi/Accepted: January 15, 2014

\section{*Corresponding author:}

Dr. Metin Şenol, Genel Cerrahi Kliniği, Nevşehir Devlet Hastanesi, TR-50300 Nevşehir. E-mail: drmetinsenol@gmail.com

\section{Introduction}

Bezoars are foreign bodies in the gastrointestinal tract. If they are stones, then named as lithobezoar. These foreign bodies can be hair, fibers or seeds of vegetables and fruits, remnants of milk and stones. The commonly reported bezoar cases are trichobezoars and phytobezoars. They are usually seen in young girls with psychological and emotional disturbances. Although the stomach is the expected site for bezoar, it can be rarely seen in colon [1]. Colonic lithobezoar is seen rarely and may cause mechanical intestinal obstruction. It is mostly seen in psychologically ill patients and also iron deficiency anemia [2]. In this case, we report a 35-year-old schizophrenia patient admitted by ileus, colonic lithobezoar was diagnosed and successfully treated by evacuation of the stones under general anesthesia.

\section{Case report}

A 35-year-old male patient was admitted to emergency service with abdominal pain. He also complained about constipation for three days. He was a schizophrenia patient and resident at a nursing home. His vital parameters were normal. Abdominal examination 
revealed distention and mild tenderness but no signs of peritonitis. Rectal examination demonstrated that there were hard masses like fecaloids. Some of these masses were extracted and seen that they're stones. The laboratory studies revealed anemia consistent with iron deficiency. Except anaemia there wasn't any pathological result. The abdominal $\mathrm{x}$-ray demonstrated dense opacities at various sizes in the entire colon (Figure 1).

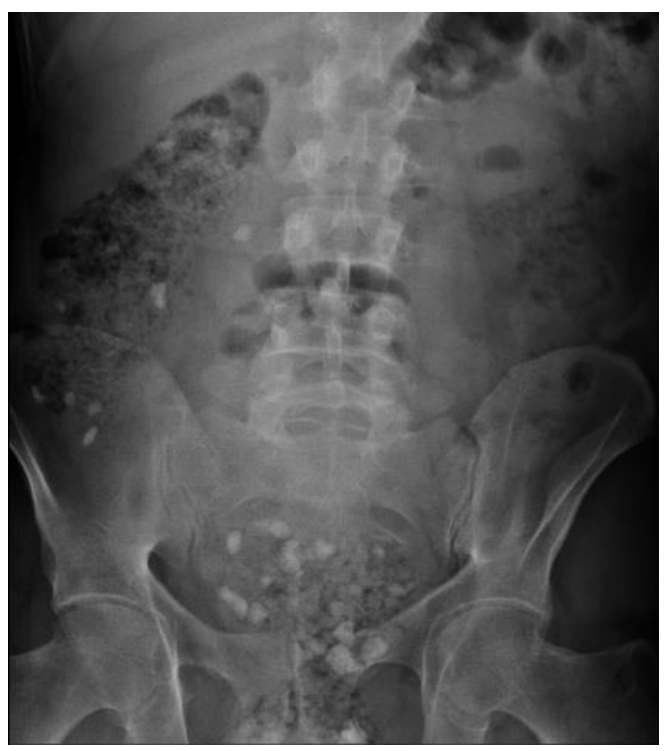

Figure 1. Abdominal X-ray.

Under general anesthesia, after anal dilatation, lots of stones were recovered by manual evacuation and colonic lavage (Figure 2). Various sizes of stones were extracted (Figure 3). He was given also rectal enemas and laxatives after the operation. He continued to pass out stones for three days. On the postoperative 4th day, his abdominal x-ray revealed no sign of stones. He was consultated to a psychiatrist and his medicines for schizophrenia were changed. After an uneventful follow up he was discharged.

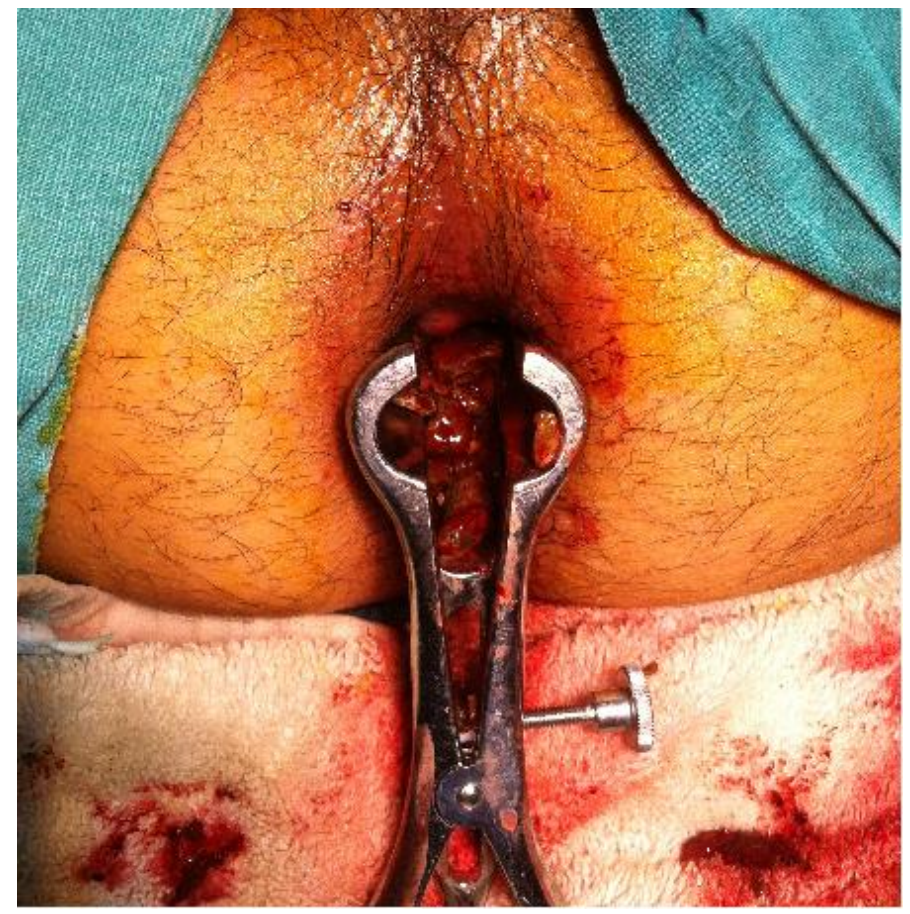

Figure 2. Anal dilatation and evacuation of the stones. 


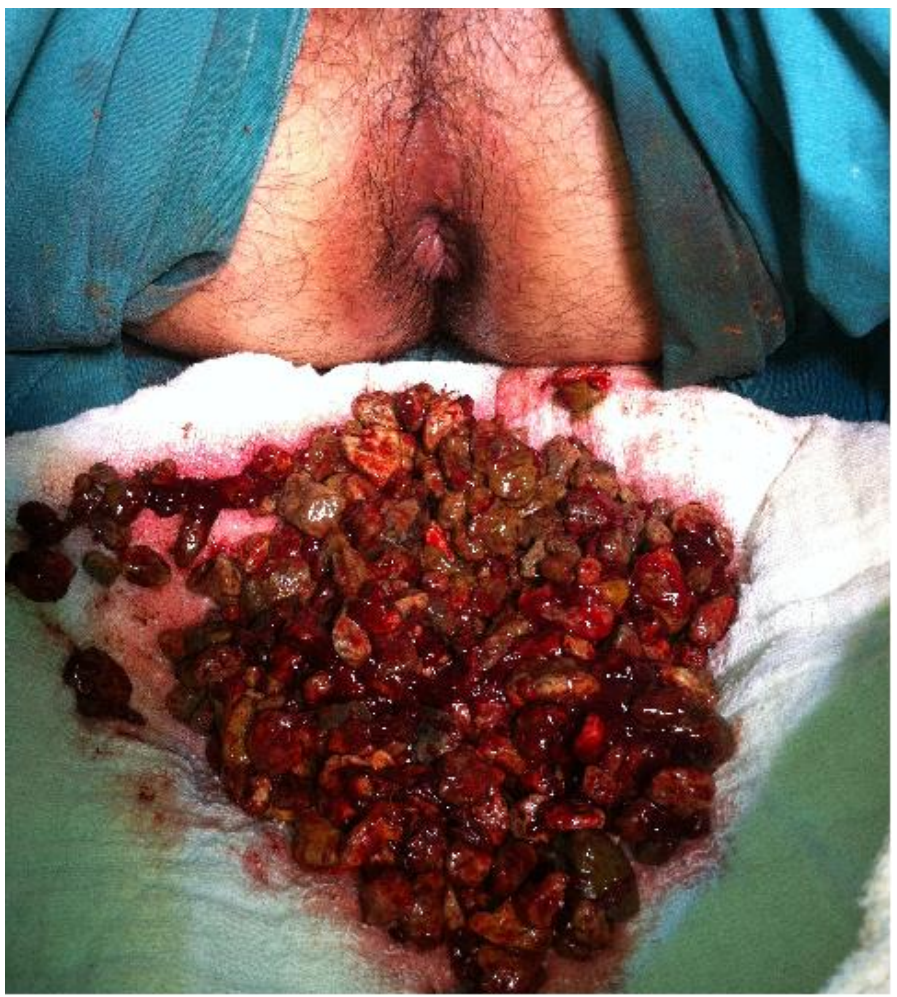

Figure 3. Various sizes of stones were extracted.

\section{Discussion}

Bezoar is defined as undigested foreign bodies or nutrients in gastrointestinal tract. Lithobezoar; the accumulation of stones, is mostly seen in the stomach. Besides, few cases have been reported within the colon. Most of the reported cases are pediatric patients [3].

Lithobezoar can be a result of pica or psychiatric disorder. Pica is the persistent craving and eating of nonfood substances. The etiology of pica is multifactorial including iron deficiency anemia or psychiatric diseases. These psychiatric disorders are schizophrenia, autism, obsessive-compulsive disorder or mental retardation $[4,5]$. In our case the patient was schizophrene, he also had iron deficiency anemia and pica. He was living at a nursing home and it was learned that he wasn't taken to hospital for his last few psychiatric controls.

Clinical findings change according to the site of the bezoar. Gastric bezoars which are the most commonly seen, present with nausea, vomiting, loss of appetite, weight loss and ulceration. On the other hand colonic bezoars present with sign and symptoms of bowel obstruction. In physical examination abdominal distention and tenderness is mostly seen. Usually, a palpable abdominal mass is found and it's named as "colonic crunch sign" [6]. At rectal examination, stones can be palpated and extracted. Also in this case, the stones were extracted and seen after rectal examination.

Abdominal x-ray is very important in the diagnosis of colonic lithobezoars. The presence of numerous radiopaque masses at abdominal $\mathrm{x}$-ray is demonstrative. This sign is named as "corn on the cub" [7]. In this case, although there were lots of stones in the colon, the "corn on the cub" sign couldn't be seen. Because the stones were very soft and radiolucent, this translucency is due to the geological characteristics of the Cappadocia region.

The method of bezoar removal depends on the site of impaction, the size and the nature of the substance and complications [8]. Conservative managements are almost always 
enough for colonic lithobezoar. In the previously reported cases, colonic lithobezoars were treated by anal dilatation and extraction of the stones under anesthesia [3,9]. There were no need for surgery. Surgery can be considered if conservative procedures fail or colonic perforation occurs. In this case, we also performed manual evacuation of the stones and the patient was treated successfully without surgery.

In conclusion, colonic lithobezoar can be a life treatening situation by causing mechanical intestinal obstruction or colonic perforation. Fortunately, they can be treated by conservative procedures. Lithobezoar must be suspected in patients with a history of pica and obsessive-compulsive disorder. More over, the psychiatric evaluation and treatment is essential to prevent recurrences.

\section{References}

1. Şenol M, Özdemir ZÜ, Şahiner IT, Özdemir H. Intestinal obstruction due to colonic lithobezoar: A case report and a review of the literature. Case rep pediatr 2013; 2013: 854975.

2. Sheikh MS, Hilal RM, Misbha AM, Farooq AR. Colorectal lithobezoar: A rare case report. J Indian Assoc Pediatric Surg 2010;15: 62-3.

3. Narayanan SK, Akbar Sherif VS, Babu PR, Nandakumar TK. Intestinal obstruction secondary to a colonic lithobezoar. J Pediatric Surg 2008; 43: 9-10.

4. Mohammad MA. Rectosigmoid lithobezoar in a eight-year-old. Afr J Pediatric Surg 2010; 7: 38-9.

5. Khan Y, Tisman G. Pica in iron deficiency: A case series. J Med Case Rep 2010; 4: 86.

6. Numanoğlu KV, Tatlı D. A rare cause of partial intestinal obstruction in a child: colonic lithobezoar. Emerg Med J 2008; 25: 312-3.

7. Baran T, Ragip O. Abdullah O, Naim K, Giant rectosigmoid moid lithobezoar in a child: Four significant clues obtained from history, abdominal palpation, rectal examination and plain abdominal X-ray. Eur J Radiol 2004; 49: 23-4.

8. Bala M, Appelbaum L, Almogy G. Unexpected cause of large bowel obstruction: Colonic bezoar. Isr Med Assoc J 2008; 10: 829-30.

9. Vijayambika K. Lithobezoar. Indian Pediatr 2004; 41: 1168. 